Audiology Japan 36, 737 745, 1993

\title{
伝音性難聴および混合性難聴にたいする 補聴器適合の研究
}

\author{
長井今日子 \\ 帝京大学医学部耳鼻咽喉科学講座
}

\begin{abstract}
要旨：伝音性難聴および混合性難聴に適合する補聴器の調整条件を,244例の臨床例から求 めた。さらに，伝音性難聴および混合性難聴の不快レベルと快適レベルの測定を18例を対 象として行った。その結果は以下のと扔りである。1）伝音性難聴および混合性難聴に適 合した補聴器の最大出力音圧レベルは, 感音性難聴と比べ約 $4 \sim 8 \mathrm{~dB}$ 高かった。2 ) 伝音 性難聴および混合性難聴の不快レベルは, 感覚レベルで比較すると, 感音性難聴とほぼ同 等の值であった。3）伝音性難聴および混合性難聴の快適レベルも，感音性難聴とほぼ同 等の值であった。4）伝音性難聴および混合性難聴に適合した補聴器の周波数レスポンス は, 約 $6 \mathrm{~dB} /$ oct の低周波数減衰の特性であった。以上の結果から, 伝音性難聴および混合 性難聴にたいする補聴器の器種の選択では, 高出力, 高利得の補聴器は必要なく, 十分に 低周波数帯を増幅できる補聴器が良いと結論した。
\end{abstract}

$$
\text { ーキーワードー }
$$

補聴器適合，伝音性難聴，混合性難聴，不快レベル，快適レベル

\section{1.はじめに}

伝音性難聴と混合性難聴にたいする補聴器適合の研 究は十分ではなく,研究者間の見解の相違が大きい しかし,手術で十分に聴力を回復できない伝音性難聴, 混合性難聴の患者は少なくなく, 補聴器を適合させる 必要性は高い。

伝音性難聴の感音性難聴と比較した特徵は, 内耳障 害による補充現象がなく, 語音明瞭度が良好で, 詳細 な音質評価が可能なことである。混合性難聴では，伝 音性難聴と感音性難聴の特徵をともに備えていると考 えられる。伝音性難聴および混合性難聴には，それぞ れの特徵に対応して補聴器適合を行う必要がある。

補聴器の適合は, 抒もに最大出力音圧レベル, 装用 時の利得, 周波数レスポンスを調整して行う。これら の調整範囲は器種によって異なるため, 適切な調整を 行える器種の選択が, 補聴器適合の第一段階として重 要である。
本研究では, 補聴器の器種選択のために必要な適切 な補聴器の調整の值を求めた。方法として, 臨床例の 検討と聴覚心理的実験を用いた。前者の検討において は, 伝音性難聴と混合性難聴に臨床上適合した補聴器 の調整条件を感音性難聴に適合したそれと比較した。 後者の実験では，伝音性難聴と混合性難聴の実験結果 を感音性難聴および正常耳の実験結果と比較した。

\section{2. 臨床例の検討}

帝京大学耳鼻咽堠科の補聴外来で, 補聴器を決定し た伝音性難聴と, 混合性難聴の症例について, 補聴器 の最大出力音圧レベルと, 周波数レスポンスを集計し 感音性難聴と検討した。

2-1）適合した最大出力音圧レベル

2-1) -(1) 対象と方法

対象は, 昭和 57 年 11 月から平成元年 4 月の間に, 適 切な補聴器を決定した伝音性難聴100耳, 混合性難聴 144 耳である。比較の対象として感音性難聴 477 耳を加えた。 
表 1 に，対象症例の平均聴力レベル（四分法）ごとの 耳数を示した。

難聴の分類では, 気骨導差が $15 \mathrm{~dB}$ 以上で骨導閾値 $(500 \mathrm{~Hz}, 1000 \mathrm{~Hz}, 2000 \mathrm{~Hz}, 4000 \mathrm{~Hz})$ が $25 \mathrm{~dB}$ 未満の 症例を伝音性難聴とした。混合性難聴は, 気骨導差 15 $\mathrm{dB}$ 以上で骨導閾值が $25 \mathrm{~dB}$ 以上の症例とした。

最大出力音圧レベル周波数レスポンスは, 補聴器の 利得調整器を最大の位置にして, 入力音圧を $90 \mathrm{~dB} \mathrm{SPL}$ として, 補聴器特性測定装置 (Phonic Ear, HC-2000) で $2 \mathrm{ml}$ カップラで測定した。本研究では, 最大出力音 圧レベルとして，そのピーク值を採用した。

2-1)-(2) 結果

適合した補聴器の最大出力音圧レベルの平均值と標 準偏差を, 表 2 , 図 1 に平均聴力レベルごとに示した。 伝音性難聴に適合した最大出力音圧レベルの平均值
は, 平均聴力が $40 \mathrm{~dB} \mathrm{HL}$ から $50 \mathrm{~dB} \mathrm{HL}$ では平均 $116 \mathrm{~dB}$ SPLであり, 平均聴力が55dB HL から $65 \mathrm{~dB} \mathrm{HL}$ では 平均 $120 \mathrm{~dB}$ SPL であった。感音性難聴と比較すると, 約 $8 \mathrm{~dB}$ 高かった。

混合性難聴では, 平均聴力が $45 \mathrm{~dB} \mathrm{HL}$ から $65 \mathrm{~dB} \mathrm{HL}$ では平均114dB SPL であり, 平均聴力が70dB HL から $90 \mathrm{~dB}$ HL では平均 $124 \mathrm{~dB}$ SPL であった。感音性難聴と 比較すると, $4 \mathrm{~dB}$ 高かった。

2-2）適合した周波数レスポンス

2-2)-(1) 対象と方法

周波数レスポンスの検討は, 最大出力音圧レベルを 検討した症例から聴力図の似た症例を抽出して行った。 対象とした聴力図は水平型の伝音性難聴と, 水平型拧 よび高音障害型の混合性難聴の 3 種とした。対象の症 例数は, 水平型の伝音性難聴が 20 例, 水平型の混合性

表 1 対象症例の平均聴力レベルごとの耳数

\begin{tabular}{|c|c|c|c|c|c|c|c|c|c|c|c|c|c|}
\hline $\begin{array}{c}\text { 平均聴カレヘ } \mathrm{dB} \mathrm{HL} \\
\mathrm{d}\end{array}$ & 40 & 45 & 50 & 55 & 60 & 65 & 70 & 75 & 80 & 85 & 90 & 95 & 総数 \\
\hline $\begin{array}{c}\text { 感音性 難聴 } \\
\text { (耳数) }\end{array}$ & 9 & 30 & 52 & 91 & 81 & 77 & 49 & 35 & 15 & 14 & 9 & 15 & 477 \\
\hline $\begin{array}{c}\text { 伝音性難聴 } \\
\text { (耳数) }\end{array}$ & 13 & 16 & 22 & 24 & 15 & 10 & & & & & & & 100 \\
\hline $\begin{array}{c}\text { 混合性難聴 } \\
\text { (耳数) }\end{array}$ & 11 & 5 & 14 & 24 & 26 & 21 & 12 & 12 & 10 & 9 & & 144 \\
\hline
\end{tabular}

表 2 適合した最大出力音圧レベル

\begin{tabular}{|c|c|c|c|c|c|c|c|c|c|c|c|c|}
\hline $\begin{array}{c}\text { 平均聴カレベル } \\
\mathrm{dB} \mathrm{HL}\end{array}$ & 40 & 45 & 50 & 55 & 60 & 65 & 70 & 75 & 80 & 85 & 90 & 95 \\
\hline $\begin{array}{c}\text { 感 音性 難 聴 } \\
\text { dB SPL } \\
\text { (標準偏差) }\end{array}$ & $\begin{array}{l}112 \\
(6)\end{array}$ & $\begin{array}{l}108 \\
(9)\end{array}$ & $\begin{array}{l}107 \\
(7)\end{array}$ & $\begin{array}{c}112 \\
(8)\end{array}$ & $\begin{array}{c}112 \\
(7)\end{array}$ & $\begin{array}{c}113 \\
(7)\end{array}$ & $\begin{array}{l}118 \\
(7)\end{array}$ & $\begin{array}{l}119 \\
(9)\end{array}$ & $\begin{array}{l}120 \\
(4)\end{array}$ & $\begin{array}{l}122 \\
(9)\end{array}$ & $\begin{array}{l}127 \\
(5)\end{array}$ & $\begin{array}{l}126 \\
(9)\end{array}$ \\
\hline $\begin{array}{c}\text { 伝 音 性 難 聴 } \\
\text { dB SPL } \\
\text { (標準偏差) }\end{array}$ & $\begin{array}{l}116 \\
(10)\end{array}$ & $\begin{array}{l}114 \\
(7)\end{array}$ & $\begin{array}{l}121 \\
(8)\end{array}$ & $\begin{array}{l}122 \\
(8)\end{array}$ & $\begin{array}{l}118 \\
(9)\end{array}$ & $\begin{array}{l}121 \\
(5)\end{array}$ & & & & & & \\
\hline $\begin{array}{c}\text { 混 合性 難 聴 } \\
\text { dB SPL } \\
\text { (標準偏差) }\end{array}$ & & $\begin{array}{l}108 \\
(7)\end{array}$ & $\begin{array}{l}111 \\
(6)\end{array}$ & $\begin{array}{l}113 \\
(8)\end{array}$ & $\begin{array}{l}117 \\
(7)\end{array}$ & $\begin{array}{l}121 \\
(6)\end{array}$ & $\begin{array}{l}124 \\
(5)\end{array}$ & $\begin{array}{l}123 \\
(10)\end{array}$ & $\begin{array}{c}122 \\
(7)\end{array}$ & $\begin{array}{l}126 \\
(4)\end{array}$ & $\begin{array}{l}126 \\
(7)\end{array}$ & \\
\hline
\end{tabular}




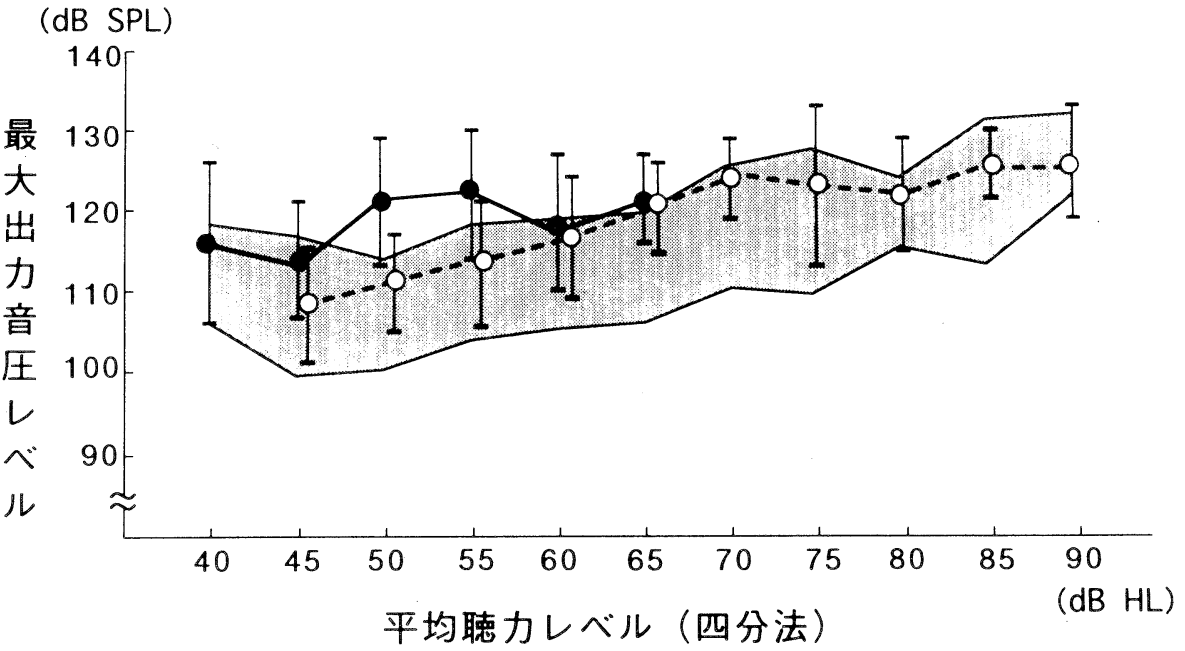

図 1 伝音性難聴と混合性難聴に臨床上適合した補聴器の最大出力音圧レベル

：伝音性難聴に適合した最大出力音圧レベルの平均値, $\bigcirc$ ：混合性難聴に適合し た最大出力音圧レベルの平均值, 図中の縦線 : 標準偏差 $( \pm 1 \mathrm{SD})$, 斜線 : 感音性難 聴に適合した最大出力音圧レベルの平均值と標準偏差（土1 SD）。
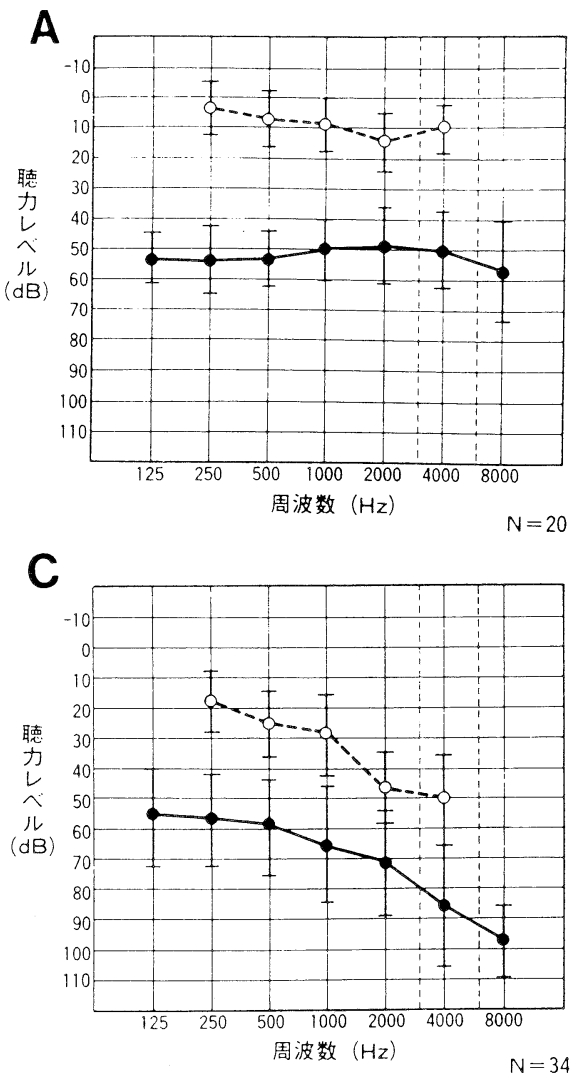

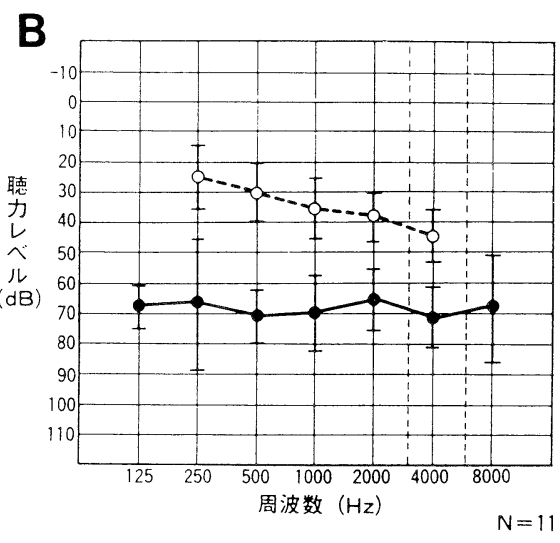

図 2 対象とした伝音性，混合性難聴者の聴力図 $\mathrm{A}$ : 水平型伝音性難聴の聴力図, $\mathrm{B}$ ：水平型混 合性難聴の聴力図, C : 高音障害型混合性難聴 の聴力図。 $\bigcirc$ : 各周波数における骨導閾值の平 均值, ○: 各周波数に打ける気導閾值の平均値。 縦線：標準偏差 $( \pm 1 \mathrm{SD})$ 。 $\mathrm{N}$ : 症例数。 
表 3 聴力型と適切な周波数レスポンスの関係

\begin{tabular}{|c|c|c|c|}
\hline 聴力図の種類 & $\begin{array}{l}1000 \mathrm{~Hz}-250 \mathrm{~Hz} \text { の } \\
\text { 低 周 波 数 減衰 } \\
\text { 平均値 （標準偏差） }\end{array}$ & $\begin{array}{l}1600 \mathrm{~Hz}-400 \mathrm{~Hz} \sigma \\
\text { 低周 波 数減衰 } \\
\text { 平均値 (標準偏差) }\end{array}$ & $\begin{array}{l}2500 \mathrm{~Hz}-315 \mathrm{~Hz} \sigma \\
\text { 低 周 波 数 減衰 } \\
\text { 平均值 (標準偏差) }\end{array}$ \\
\hline $\begin{array}{l}\text { 伝音性難聴 } \\
\text { 水 平 型 }\end{array}$ & $7.4 \mathrm{~dB} / \mathrm{oct}$ & $4.8 \mathrm{~dB} /$ oct & $6.3 \mathrm{~dB} /$ oct \\
\hline $\begin{array}{l}\text { 混合性難聴 } \\
\text { 高音障害型 } \\
\text { 水 平 型 }\end{array}$ & $\begin{array}{ll}9.0 \mathrm{~dB} / \text { oct } & ( \pm 8.8) \\
5.9 \mathrm{~dB} / \text { oct } & ( \pm 7.1)\end{array}$ & $\begin{array}{ll}5.2 \mathrm{~dB} / \text { oct } & ( \pm 7.2) \\
3.3 \mathrm{~dB} / \text { oct } & ( \pm 7.8)\end{array}$ & $\begin{array}{ll}7.1 \mathrm{~dB} / \text { oct } & ( \pm 7.9) \\
3.0 \mathrm{~dB} / \text { oct } & ( \pm 14.5)\end{array}$ \\
\hline
\end{tabular}

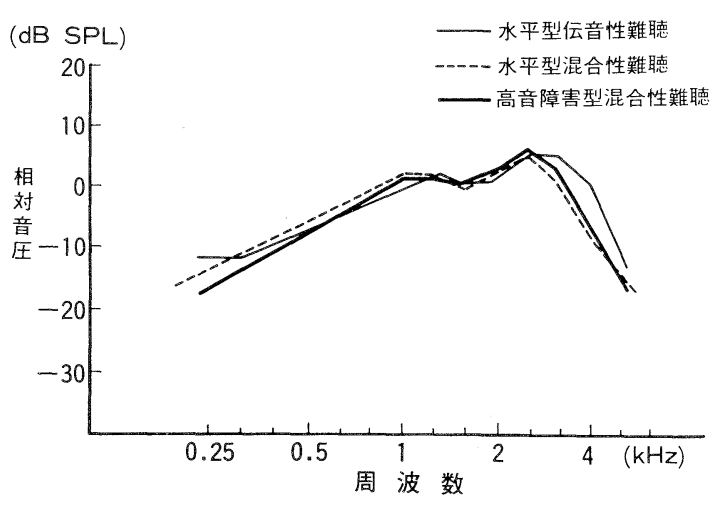

図 3 各聴力型に適合した周波数レスポンス

各聴力型の症例に適合した周波数レスポンスを， $1600 \mathrm{~Hz}$ を基準として示した。

難聴が11例，高音障害型の混合性難聴が34例である。 これらの対象症例の骨導閾値と気導閾値の平均値を図 2 に示した。聴力図の分類の基準は以下のと抢りとし た。水平型伝音性難聴は, $250 \mathrm{~Hz}$ と $2000 \mathrm{~Hz}$ の気導閾值 の差が $15 \mathrm{~dB}$ 以内のものとした (図 2-A)。水平型混合 性難聴は, $250 \mathrm{~Hz}$ と $2000 \mathrm{~Hz}$ の気導閾值の差が $15 \mathrm{~dB}$ 以 内のものとし(図 2-B), 高音障害型混合性難聴は, 4000 $\mathrm{Hz}$ と $500 \mathrm{~Hz}$ の気導閾值の差が $20 \mathrm{~dB}$ 以上のものとした (図 2-C)。

以上の聴力図を示す症例に適合した補聴器の周波数 レスポンスを, 利得を患者の使用レベルとし入力音圧 を60dB SPL として, 補聴器特性装置で求めた。ついで, $1000 \mathrm{~Hz}$ と $250 \mathrm{~Hz}$ の間と, $1600 \mathrm{~Hz}$ と $400 \mathrm{~Hz}$ の間と, 2600 $\mathrm{Hz}$ と $315 \mathrm{~Hz}$ の間で低周波数減衰の傾きの平均値と標準 偏差を求めた。

2-2)-(2) 結 果

低周波数減衰の傾きの平均值と標準偏差を表 3 亿示
した。水平型伝音性難聴では, $5 \sim 7 \mathrm{~dB} /$ oct $の$ 低周波 数隇衰の傾きを示した。この結果と比較すると, 高音 障害型混合性難聴では, わずかに高音強調となり, 水 平型では, より低音強調の傾きを示した。しかし, 図 3 に $1600 \mathrm{~Hz}$ を基準として示したように,全体的には 3 種の聴力図の間でほとんど差を認めなかった。

\section{3. 基礎的検討}

臨床上適合する補聴器の決定には, 補聴器の外観, 価格などの音響的特性以外の要素が関与している。こ れらの要素を除いた適合する音響的特性を求める目的 で，少数例を対象に基礎的検討を加えた。

基礎的検討では, 朗読者に対する不快レベルと快適 レベルを測定した。朗読音を検査音に選択した理由は, 純音に比べてょり実際的と考えられるからである。

検査音のレベルには, 自覚閾値を基準とした感覚レ ベル (dB SL) を用いた。その理由は, 朗読音のレベル 分布が広い周波数带に渡ること, 聴力図や対象によっ て異なること, 測定方法としてスピーカ法とイヤホン 法を用いたことなどによって生じるレ心゙ル比較の困難 性を, 感覚レベルを採用することで避けるためである。 3-1）スピーカ法による快適レベルと不快レベルの測定 3-1)-(1) 対象と方法

対象は, 平均気導閾值 $47 \mathrm{~dB} \mathrm{HL}(\mathrm{SD}=7.7)$, 平均骨 導閾值 $15 \mathrm{~dB}$ HL $(\mathrm{SD}=4.2)$ の両側伝音性難聴 9 耳と, 平均気導閾值 $57 \mathrm{~dB} \mathrm{HL}(\mathrm{SD}=7.0)$, 平均骨導閾值 $29 \mathrm{~dB}$ HL $(\mathrm{SD}=3.0)$ の両側混合性難聴 9 耳とした。比較の ために, 正常聴力者 8 耳 (平均年齢25.6歳, $\mathrm{SD}=5.0$ ) と平均気導閾值 $52 \mathrm{~dB} \mathrm{HL}(\mathrm{SD}=9.0)$ の両側感音性難 聴 7 耳 (平均年齢51.7歳, $\mathrm{SD}=9.0$ ) を対象に加えた。 図 4 に対象者の聴力図を, 平均值と標準偏差で示した。 快適レベルと不快レベルの測定では, 被検者をスピ 
一カの前 $1 \mathrm{~m}$ の位置にスピーカにたいして横向きに着 席させ検査を行った。検查は良聴耳で行い，非検査耳 はマフで遮蔽した。マフの遮蔽量は, $125 \mathrm{~Hz}: 13 \mathrm{~dB}$, $250 \mathrm{~Hz}: 24 \mathrm{~dB}, 500 \mathrm{~Hz}: 27 \mathrm{~dB}, 1000 \mathrm{~Hz}: 30 \mathrm{~dB}, 2000$ $\mathrm{Hz}: 39 \mathrm{~dB}, 4000 \mathrm{~Hz}: 44 \mathrm{~dB}$ である。

測定音として，男性の朗読音を録音したテープ（新 潮社カセットブック，井伏鱒二著「鯉」）を用いた。こ の測定音は，以前に著者らが会語音にたいする快適レ ベルと不快レベルの研究6)に用いたものと同一である。 朗読音のパワースペクトラムの測定は，被検者の耳元 の位置に騒音計（RION NA-20）を打き, 等価騒音レ ベルユニット（RION EQ-5) を接続して行った。 $A$ 特 性のレベル分布は, $500 \mathrm{~Hz} \sim 1000 \mathrm{~Hz}$ で最大で, 最大音 声勢力と平均音声勢力のレベル差は, over all level で

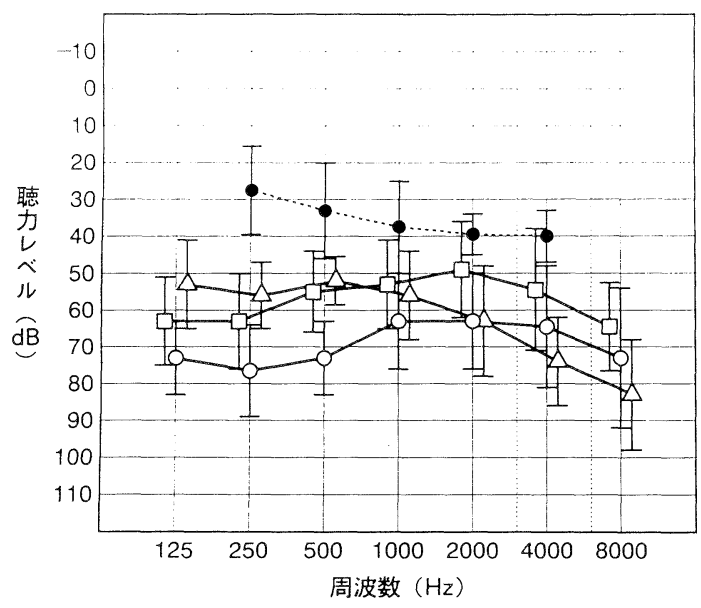

図 4 不快レベルと快適レベルを測定した対象症例の 聴力眓

：混合性難聴の骨導閾值の平均值， $\square$ : 伝音 性難聴の気導閾值の平均值， $\bigcirc$ : 混合性難聴の 気導閾值の平均值, $\triangle$ : 感音性難聴の気導閾值 の平均値, 縦線：標準偏差 $( \pm 1 \mathrm{SD})$ 。

表 4 快適レベルと不快レベルの測定における指示

自覚䦭値「音がかすかに聞こえます。」

CLの下限「ちょうど良いですが,少し音が小さいです。」

MCL 「ちょうど良いレベルです。」

CLの上限「ちょうど良いですが,少し音が大きいです。」 UCLの下限「うるさいですが, しばらくの間は聞いてられます。」 UCL 「うるさくて,聞いてられません。」
C特性で10.3dB，A特性で9.7dB である。

快適レベルと不快レベルの測定は, このテープをカ セットレコーダ (SONY HX PRO) で再生し, 幼児聴 力検查装置 (RION AA-80) に導き増幅し, 防音室 (RION AT-70) の壁から $10 \mathrm{~cm}$ の位置に設置したスピ 一カー (VICTOR ZERO $90 ; 100 \mathrm{~Hz}$ から $20000 \mathrm{~Hz}$ ま で平坦な特性で, 出力レベルの直線性は約 $100 \mathrm{~dB}$ まで ある）より被検者に聞かせた。検査音の提示時間は約 15秒間とし， $5 \mathrm{~dB}$ ステップで検査音のレベルを上昇さ せた。被検者の快適レベルと不快レベルの応答では， 表 4 に示した自覚閾値, 快適レベルの下限 (CL の下限), 最も快適なレベル $(\mathrm{MCL})$, 快適レベルの上限 $(\mathrm{CL}$ の) 上限)，不快レベルの下限 (UCL の下限)，たいへん不 快なレベル（UCL）の6段階の評価のカードを手わた し, 各検査音のレベルごとに対応したカードを提示さ せた。なお，測定值の再現性を確認するために反復し て 2 回検查を行ったが，1回目と2 回目の検査結果に 差を認めなかったので，本研究の分析には 2 回目の測

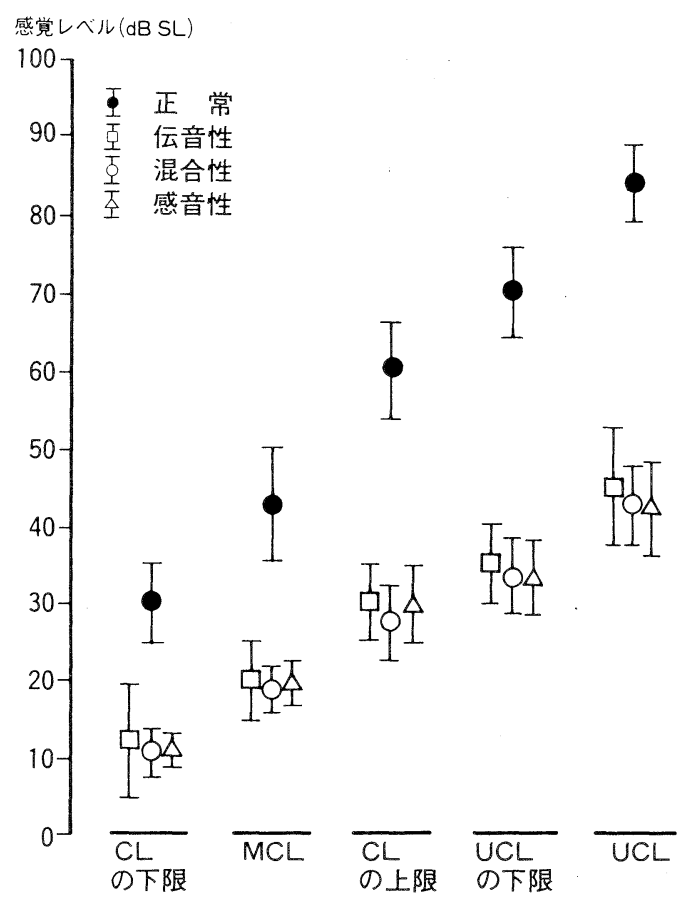

図 5スピーカ法に打ける不快レベルと快適レベル

：正常聴力者に打ける平均值， $\square$ : 両側伝音 性難聴の平均值, $\bigcirc$ : 両側混合性難聴の平均值, $\triangle$ : 両側感音性難聴の平均值。綐線：標準偏差 $( \pm 1 \mathrm{SD})$ 。 


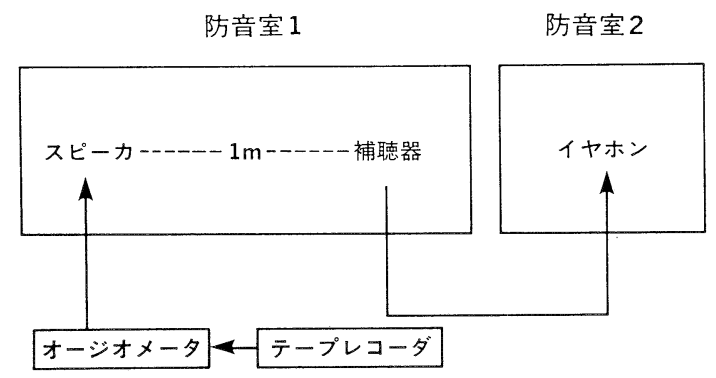

図6 補聴耳における不快レベルと快適レベルのブロ ックダイヤグラム

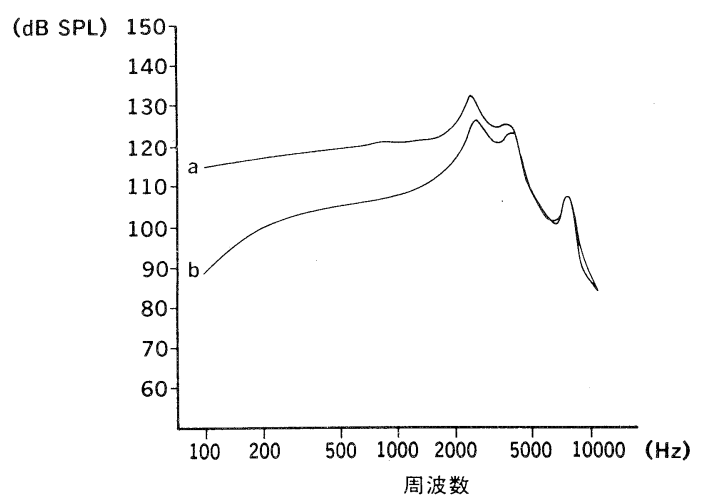

図 7 検査に用いた補聴器の特性

$\mathrm{a}: 90 \mathrm{~dB}$ 最大出力音圧レベル周波数レスポン ス。b：実験で用いた利得の条件で，マイクロ ホン入力を $60 \mathrm{~dB}$ SPL として測定した音響利得周 波数レスポンス。

定值を用いた。

3-1)-(2) 結 果

図 5 に, スピーカ法による快適レベルと不快レベル の結果を示した。正常聴力者の快適レベル（快適レベ ルの下限から上限まで）は，33dB SL から60dB SL で あった。また, 不快な感覚は72dB SL からはじまり(不 快レベルの下限), $84 \mathrm{~dB}$ SL で強かった。一方, 両側混 合性難聴，伝音性難聴では，正常聴力者のそれと比較 すると不快レベルは約42dB SL で，快適レベルは約 20 $\mathrm{dB} \mathrm{SL}$ と著しく低く, しかも，感音性難聴とほぼ同等 のレベルであった。

3-2）補聴耳の快適レベルと不快レベルの測定

3-2)-(1) 対象と方法

対象は，実験 1 の被検者と同一である。図 6 亿補聴 耳の快適レベルと不快レベルの測定方法を示した。す なわち, 防音室 1 にスピーカから $1 \mathrm{~m}$ の距離に補聴器

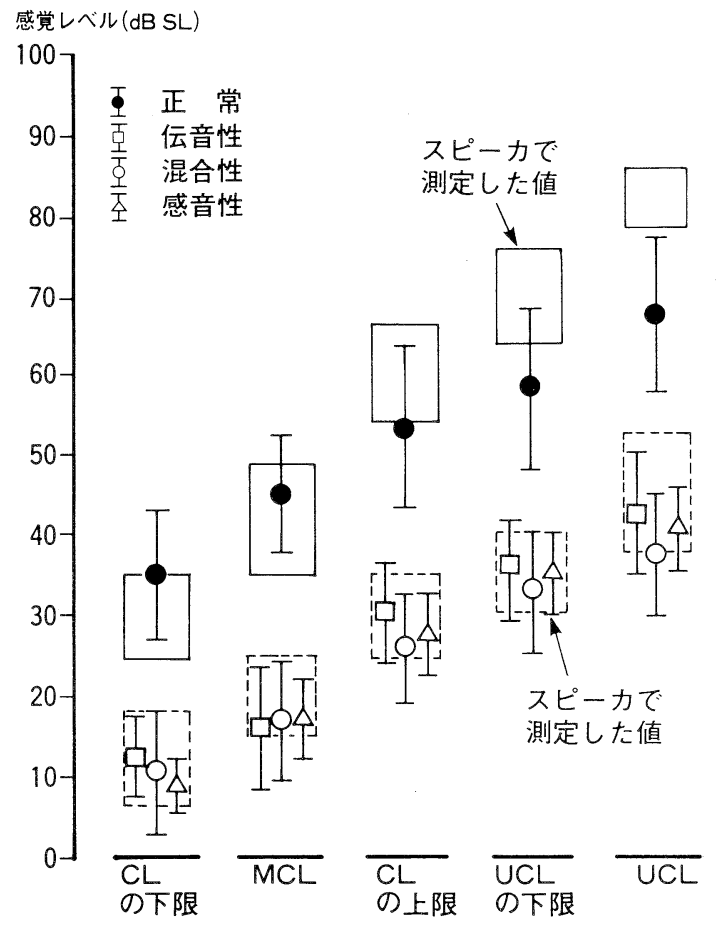

図 8 補聴耳における不快レベルと快適レベル

○：正常聴力者における平均値， $\square$ ：両側伝音 性難聴の平均値, $\bigcirc$ : 両側混合性難聴の平均値, $\triangle$ : 両側感音性難聴の平均値。緹線：標準偏差 $( \pm 1 \mathrm{SD})$ 。比較のために, スピーカで測定した 值 (平均值 \pm 1 標準偏差) を長方形の枠で示し た。

（RION HA-56W）を設置し，増幅した電気信号を防 音室 2 に導き，イヤホン（RION 75B）を通して被検 者に検查音を提示した。なお, 測定に用いた補聴器の 特性は, 前出の測定装置により行い, その結果を図 7 に示した。すなわち, 最大出力音圧のピーク值は $134 \mathrm{~dB}$ $\mathrm{SPL}$, 音質は $\mathrm{N}$, 音響利得を $1600 \mathrm{~Hz}$ で52dB とした。 検査音の提示方法や，快適レベルと不快レベルの測定 方法は，スピーカ法と同一とした。

3-2)-(2) 結 果

図 8 に補聴耳の快適レベルと不快レベルを, 感覚レ ベルで示した。正常聴力者の補聴耳の快適レベルは, スピーカ法によるそれと比較すると快適レベルの下限 は約 $5 \mathrm{~dB}$ 高く, 快適レベルの上限は約 $10 \mathrm{~dB}$ 低かった。 また，不快レベルは，スピーカ法と比べると，約 $15 \mathrm{~dB}$ 低かった。伝音性難聴, 混合性難聴, 感音性難聴を比 較すると, 伝音性難聴でわずかに高い傾向を認め, 混 
合性難聴，感音性難聴ではほぼ一致した。

\section{4. 考察}

4-1）不快レベルと適合する最大出力音圧レベル

感音性難聴にたいする最大出力音圧レベルの調整は, 補充現象にあわせて, 個々の症例に応じた設定が必要 であると考えられている7,8)。一方，伝音性難聴では， 内耳障害による補充現象がないため, 不快レベルは感 覚レベルの值として正常人と同等であるとみなす考え 方が一般的である ${ }^{9,10)}$ 。

ところが, 本研究における臨床的検討では，伝音性 難聴に適合した最大出力音圧レベルは, 感音性難聴の 場合と比較すると, 約 $8 \mathrm{~dB}$ しか高くなかった。また, 混合性難聴では, 感音性難聴と比較すると, 約 $4 \mathrm{~dB}$ 乙 か高くなかった。

当補德外来における補聴器決定では, 複数の補聴器 を同時に貸出し，日常生活で試聴させ，問診を繰り返 して微調整を行っている。この方法の問題点として, 市販されている補聴器の中で選択させていることと， 価格や外観も器種決定の重要な要素となっているため, 音響的特性が最適なものではない可能性が否定できな い。

本研究の基礎的実験で得られた結果は，臨床的検討 を行った対象に補聴器が良く適合していたことを支持 するものであった。すなおち，両側性の伝音性難聴， 混合性難聴の不快レベルは, スピーカ法で約45dB SL, 補聴器法で約 $42 \mathrm{~dB}$ SL と正常聴力者と比較すると著し く低く，しかも，感音性難聴の不快レベルとほほ同等 の值であった。つまり，臨床例の検討からえた最大出 力音圧レベルの值は，伝音性難聴および混合性難聴に よく適合する值であると考えられた。

従来の伝音性難聴の不快レベルの研究の報告では, 検査音に純音を用いて打り，結果は報告者によって大 きく異なっている。大橋 ${ }^{9}$, 新井 ${ }^{10)}$ は, 本研究結果とく らべ約 $20 \mathrm{~dB}$ 高い值を報告している。一方, Silverman ${ }^{11)}$, 斉藤 $^{12)}$, 立木 ${ }^{13,14)}$, 海野15) らは, 伝音性難聴でもリクル 一トメントに類似した現象が認められると報告してお り, 本研究で求めた伝音性難聴, 混合性難聴の不快レ ベルは, 立木, 海野の研究結果とほぼ一致した。

本研究の特徵は, 両側性難聴の患者を対象としてい ることである。ところが，過去の報告の多くは，一側 性の伝音性難聴を対象としている。著者らの結果が比 較的低い值の報告と一致した原因には，難聴の原因疾 患が慢性中耳炎や中耳奇形などであるため，長期間の
難聴の生活が関与していると推測している。また，補 聴器決定後の経過観察でも, 補聴器を常用する伝音性 難聴患者で, 利得と最大出力が不足する印象は少ない。 4-2）伝音性難聴および混合性難聴の快適レベルと補聴 器の利得

本研究における伝音性難聴および混合性難聴の快適 レベルの自覚閾值上の值は，不快レベルと同様に正常 者とくらべ著しく低く，感音性難聴と同等のレベルで あった。両側性難聴なので，不快レベルと同じく快適 レベルも低くなったと考えられる。

従来の伝音難聴の快適レベルの報告は，著者らの調 心゙た範囲では，海野14)，立木 ${ }^{12,13)}$ の報告を認めるのみ である。これらの報告と本研究結果を比べると, 海野 の報告とほぼ一致し，立木の報告より約 $5 \mathrm{~dB}$ 低かった。 伝音性難聴と感音性難聴の快適レベルが一致した点と, 正常者よりも低い点でこれらの報告と本研究結果は一 致した。

一般に, 難聴者は, 補恥器装用時には, 快適レベル で会話を聞き取れるように音響利得を調節する16)。伝音 性難聴，混合性難聴の快適レベルは，感音性難聴と同 様であるので, 特別に利得の大きい補聴器は不要であ ると考えられる。

ところで, 適切な補聴器の音響利得を求める方法の 一つとして，選択的増幅法による計算式が提唱されて いる。伝音性難聴，混合性難聴にたいしては，感音性 難聴に必要な利得に，オージオグラム上の伝音成分の 補正を行う方法が用いられている。表 5 に, 各研究者 の提唱した伝音成分の補正值を比較して示した ${ }^{1 \sim 5)}$ 。こ れらの, 補正值を比較すると, 報告者によって值が大 きく異なっている。Lyregaard ${ }^{1,2)}$ の場合では, 補正後 の装用時利得が他と比べ，より大きくなっている。 Lyregaardの補正值は，伝音性難聴の自覚閾值:上の快

表 5 補聴器の音響利得を選択的増幅法によって求め るさいの伝音成分の補正值

\begin{tabular}{|l|r|}
\hline \multicolumn{1}{|c|}{ 著者名 } & \multicolumn{1}{|c|}{ 補 正 值 } \\
\hline P. E. Lyregaard (POGO) & $1 / 2$ (A-B gap) \\
\hline E. R. Libby & $1 / 4$ (A-B gap) \\
\hline S. F. Lybarger & $1 / 4$ (A-B gap) \\
\hline K. W. Berger & $1 / 5$ (A-B gap) \\
\hline
\end{tabular}

$(A-B$ gap $=$ 気 - 骨導差 $)$ 
適レベルと不快レベルは，正常聴力者と同等であると みなす考え方から導きだされている。

一方, Berger ${ }^{5)}$ や Libby $^{4)}$ は, より少ない補正値を提 唱しておりり, 伝音性難聴, 混合性難聴は感音性難聴に 近いという考え方に基づいていると考えられる。本研 究で, 伝音性難聴, 混合性難聴の快適レベルが, 感音 性難聴と同等のレベルであったことから, 伝音性難聴, 混合性難聴に適合する補聴器の利得を求める計算式で は，伝音成分の補正は小さくて良いと考えられる。

な押, 補聴器をとおした場合の伝音性難聴, 混合性 難聴の不快レベルと快適レベルは，スピーカ法で求め た値と比べ, 低い傾向が認められた。補聴器をとおし たことで, 音質が劣化すると不快レベルと快適レベル がより低くなると考える。

4-3）適合する補聴器の周波数レスポンス

補聴器の周波数レスポンスは, 補聴器をと扝した音 の音質の改善と語音弁別の改善に関与している ${ }^{17)}$ 。伝音 性難聴，混合性難聴に適合する周波数レスポンスに関 する研究は, 著者らの調べた範囲では Davis ${ }^{18)}$ の報告 以外に認められない。しかし, 伝音性難聴, 混合性難 聴は, 内耳の障害が少ないため, 音質に関して敏感で あると考えられ，これらの難聴にたいしても適切な周 波数レスポンスの研究は必要である。

本研究における伝音性難聴, 混合性難聴に適合した 周波数レスポンスは, いずれも, 約 $4 \sim 6 \mathrm{~dB} /$ oct の低 周波教減衰の特性であった。Davis による報告と比較す ると,Davis の測定方法はへッドホンによる測定結果で あるため, 現代の補聴器との直接的な比較は困難であ るが, 聴力や難聴の種類にかかわらず， $6 \mathrm{~dB} /$ oct の高 音強調がよいという結果とほぼ一致した。また, 感音 性難聴に適合する周波数レスポンスを聴力図別に検討 した堀内ら ${ }^{19)}$ の報告と比較すると, 本研究で求められ た伝音性難聴, 混合性難聴に適合した周波数レスポン スは，より低音を増幅した特性となった。

広田 ${ }^{20)}$ らは，周波数特性と音質の関係における報告 で，とくに自然で柔らかな感じをもとめる場合， $6 \mathrm{~dB} /$ oct の低周波数減衰の特性がよいと述べている。低域を より強調した本研究結果は, 音質がより, 自然で柔ら かな感じを好む傾向にある伝音性難聴，混合性難聴に 適合したと考元られた。伝音性難聴，混合性難聴に対 する補聴器の適合では, 低域の周波数帯をより強調で きるものを選択する必要がある。

\section{4.まとめ}

両側性の伝音性抢よび混合性難聴を対象とし, 臨床 上適合した補聴器の調整条件（最大出力音圧レベル, 周波数レスポンス) を検討した。また，基礎的検討と して，不快レベルと快適レベルの測定を行い，以下の 結果と結論を得た。

1) 臨床上適合した補聴器の最大出力音圧レベルは, 伝音性難聴では, 感音性難聴と比べ約 $8 \mathrm{~dB}$ 高く, 混 合性難聴では約 $4 \mathrm{~dB}$ 高かった。基礎的実験では, 伝 音性難聴抒よび混合性難聴の不快レベルは, 正常者 と比べ約 $40 \mathrm{~dB}$ 低く,感音性難聴とほぼ同等であった。 伝音性難聴, 混合性難聴には, 最大出力音圧レベル が特に高い器種を選択する必要はない。

2 ）伝音性および混合性難聴の快適レベルは, 自覚閾 值上約 $20 \mathrm{~dB}$ で, 感音性難聴とほぼ同等の值であった。 伝音性難聴および混合性難聴には，音響利得が特に 高い器種を選択する必要はない。

3 ) 伝音性難聴および混合性難聴に適合する補聴器の 周波数レスポンスは,いずれの聴力図でも, 約 $6 \mathrm{~dB} /$ oct の低周波数減衰の特性であった。伝音性および混 合性難聴には, 低音域を十分に増幅できる器種を選 択すべきである。

謝辞：稿を終えるに当たり，ご指導，ご校閲を賜った 帝京大学耳鼻咽喉科講座 鈴木淳一教授, 小寺一興助 教授に深甚なる謝意を捧げます。また，本研究に際し， ご協力を賜った帝京大学医学部付属病院耳鼻咽喉科補 聴外来のスタッフの方々により感謝致します。

\section{A Study on Fittings of Hearing Aids for Conductive and Mixed Hearing Losses}

Kyoko Nagai

Department of Otolaryngology, Teikyo University School of Medicine

The purpose of this study is to find appropriate electroacoustic characteristics of hearing aids to fit to the patients with a conductive or mixed hearing loss. In analysis of the clinical records of 100 cases of conductive loss, 144 cases of mixed loss and 477 cases of sensorineural hearing loss, the most suitable maximum output-sound-pressure-level (MOSPL) and the most suitable frequency responses 
of hearing aids for conductive and mixed hearing losses were studied. In addition, the uncomfortable levels (UCLs) and the most comfortable levels (MCLs) were measured in 25 patients. They consisted of 9 cases of conductive loss, 9 of mixed hearing loss and 7 of sensorineural loss. The results were summarized as follows: (1) In the cases with conductive hearing loss, the averaged optimal MOSPL was about $8 \mathrm{~dB}$ higher than that of the sensorineural hearing loss at each hearing level. In the cases with mixed hearing loss, it was about $4 \mathrm{~dB}$ higher than that of sensorineural hearing loss. (2) The most suitable frequency response for conductive and mixed hearing losses was that with a low-frequency cut-off slope $6 \mathrm{~dB} /$ octave. (3) The UCLs and MCLs in the cases of conductive and mixed hearing losses were almost the same as in sensorineural hearing loss. As a conclusion, for conductive and mixed hearing losses, the hearing aids with a high maximum output level were not necessary. The hearing aids with the sufficiently amplified low frequencies were found appropriate.

\section{引用文献}

1) McCandless GA and Lyergaard PE : Prescription of gain/out put (POGO) for hearing aids. Hearing Instruments 34:16-21, 1983

2 ) Lyregaard PE: On the practical validity of POGO. Hearing Instruments 37 : 13-16, 1986

3 ) Lybarger SF : Fitting manual for models 980 , 980-A. Radioear Corp., Canonsburg, 1963, pp1-4

4) Libby ER : State-of-the-art of hearing aid selection procedures. Hearing Instruments $36: 30-40$, 1985

5 ) Berger KW : Prescription of hearing Aids. (日 本語版）メディカルジャーナル，東京， 1986, pp24

6 ）長井今日子, 小寺一興, 前田知佳子, 他：会話音 にたいする快適レベルと不快レベルの測定。Audiology Japan 34:259-264, 1991

7 ) 小寺一興, 工藤多賀, 広田栄子, 他：中等度難聴 者に適合する補聴器の最大出力音圧レベル。 Audiology Japan 27：112-117, 1984

8 ) 広田栄子, 小寺一興: 補聴器の最大出力音圧の語
音明瞭度への影響。耳鼻臨床 $77: 793-801,1984$

9 ) 大橋格: 不快感発現音響強度域に関する研究。日 耳鼻 63: 1032-1061, 1960

10）新井邦夫：リクルートメント検查法としての快適 大きさ曲線。耳鼻臨床 47：400-403, 1955

11) Silverman SR and Louis ST: Tolerance for pure tones and speech in normal and defective hearing. Ann. Otol. Rhinol. Laryngol. 56 : 658677, 1947

12）斉藤彰：聴覚の不快レベルに関する臨床的研究。 日耳鼻 74：28-46, 1970

13）立木孝：Recruitment 測定法の検討 (1)。耳堠 $28: 13-19,1956$

14）立木孝：Recruitment 測定法の検討 (2)。耳喉 $28: 403-410,1956$

15）海野佐金次：補聴器適応検査に関する実験的研究 並びに臨床的応用。日耳鼻 72：1339-1373, 1969

16) Watson NA and Knuden VO: Selective amplification in hearing aid. J. Acoust. Soc. Am. 11 : 406-419, 1940

17）広田栄子，小寺一興，佐川幸子：語音明瞭度の差 にもとづいた補聴器の適合一中等度感音性難聴者に おりる検討一。耳鼻と臨床 28：174-179, 1982

18) Davis H, Hudgins RJ, Marquis RJ, and et al. : The selection of hearing aids. Laryngoscope $\mathbf{5 6}$ : 19-21, 1946

19）堀内美智子, 小寺一興：中等度感音難聴者に適合 する補聴器の周波数特性。Audiology Japan 26:729 -734, 1983.

20）広田栄子, 小寺一興：補聴器の音質と電気音響学 的特性の関係一感音難聴者に打ける検討一。 Audiology Japan 27 : 144-152, 1984

(原稿受付 平成 5.7.1)

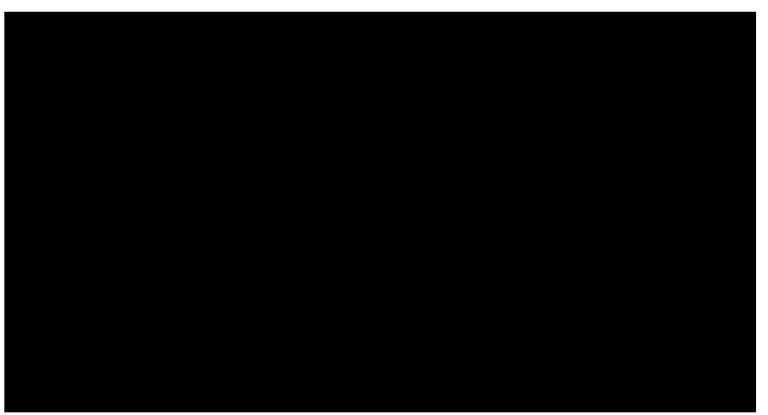

